\title{
EXCHANGES OF WATER BETWEEN THE ENGLISH AND BRISTOL CHANNELS AROUND LANDS END
}

\author{
By L. H. N. COOPER, D.SC. \\ The Plymouth Laboratory
}

(Text-figs. I-I I)

An understanding of the oceanography of the Celtic Sea requires an understanding of the exchanges of water around four headlands, Ushant, Lands End, St Davids Head and Carnsore Point. As a sequel to the study on the flow past Ushant already presented (Cooper, $1960 b$ ), this paper and the following one by Cooper, Lawford \& Veley are attempts to achieve a better understanding of the exchanges around Lands End and in the neighbourhood of the Scilly Isles (Fig. I).

Matthews (I9I4, p. 20) said: 'The charts published in this report show that the saltest water enters the Irish area between Lands End and the Scilly Islands, and detailed observations made along this line on several cruises at intervals of from half a mile to one mile on the Marine Biological Association's steamers have shown that the axis of highest salinity lies midway between the Longships Rock and the Seven Stones Lightship, that is, at a distance of only a few miles off Lands End. This current of salt warm water is derived from a current which has already entered the English Channel from a southwesterly direction, and has in part turned northwards and north-westwards to escape into the Irish Channel. It is practically certain that this water has come from the mouth of the English Channel and not directly from the open sea because further westwards a great area of lower surface salinity stretches southwards across the fairway and prevents any such direct current.'

Harvey (1925, fig. 19) accepted Matthews' interpretation and later (1929) from a study of geopotential topographies deduced that a residual current ran between Lands End and the Scillies in June 1924 in a N.N.E. direction with a velocity of about $\mathrm{I} \frac{1}{2}$ miles per day compared with the water at $60 \mathrm{~m}$. Carruthers (I934) suspected that N.N.E. may be a misprint for N.N.W. but both descriptions could be applied to different parts of the course sketched; N.N.E. applies more nearly in the passage itself.

The current measurements of Carruthers, Lawford \& Veley (195I) further discussed in the following paper (Cooper, Lawford \& Veley, I960) cannot be gainsaid but appeared gravely to conflict with the deductions of Matthews and of Harvey. 
Lumby (1935, p. 33) also remarked that 'an area of small extent (in the neighbourhood of the 'Seven Stones') appears to have a different régime from the rest of the Channel, according to the fluctuations of salinity from year to year. The same probably applies also to the seasonal variation.' Lumby \& Carruthers et al. are thus in agreement. If measurements of current, temperature and salinity at the Seven Stones Light Vessel are considered to represent the whole of the Lands End-Scilly passage, we have no choice but to reject the deductions of Matthews and Harvey.

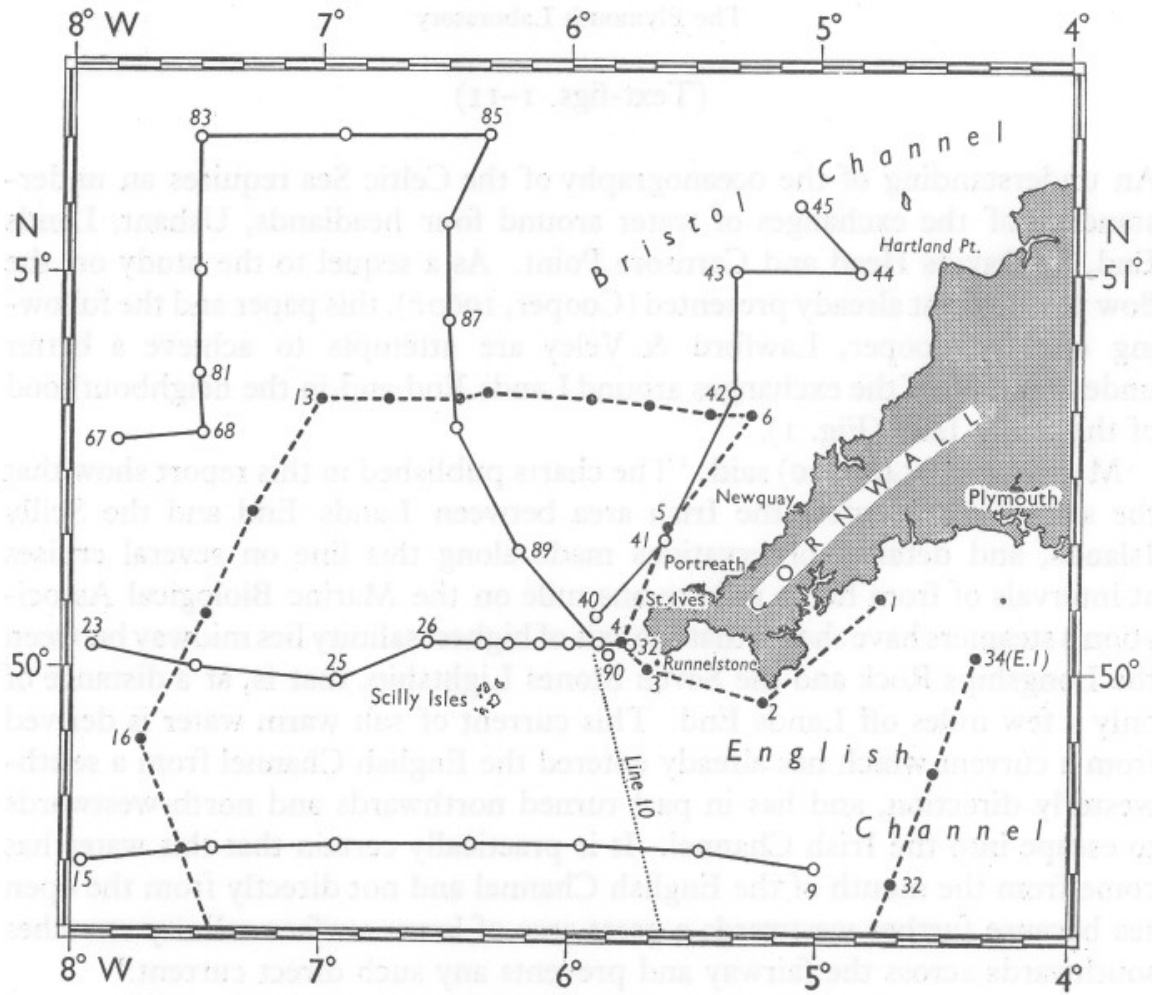

Fig. I. Chart of area discussed and stations worked in April (full lines) and June 1950 (pecked lines).

The conflict may be resolved if we assume, as Matthews implied, that measurements at the light vessel may not be representative of the whole width of the passage and that a narrow corner current with other characteristics may flow snugly around Lands End from the south coast to the north coast of Cornwall. This was the state of our knowledge when our 1950 cruises were planned. The results, as first appreciated, were equivocal.

But let us start by examining the observations of salinity and temperature at the Seven Stones Light Vessel; as observations, these have quite exceptional homogeneity and apparent reliability. 
TABLE 1. THE MEAN TEMPERATURE AND SALINITY IN REGION 5 (=SEVEN STONES LIGHT VESSEL) FOR MONTHS AND YEARS OF THE PERIOD 1928-58

Continuation of Lumby (I935; Table r6)

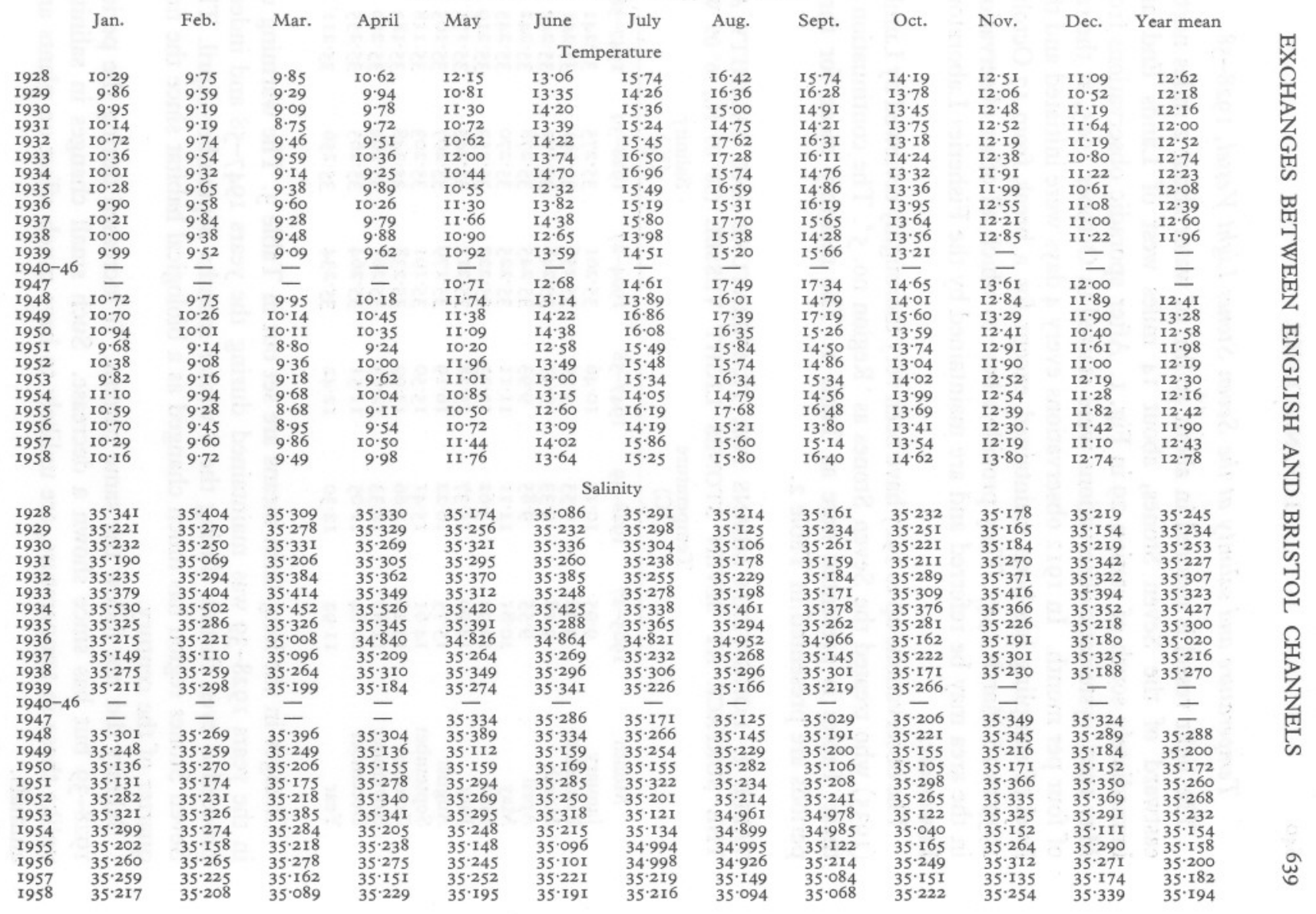




\section{Temperature and salinity at the Seven Stones Light Vessel, 1928-58}

The light vessel is moored in about $40 \mathrm{fm}$. of water about 2 miles northeastward of the Seven Stones, about I4 miles west of Lands End and immediately south of station 29 in Fig. I. After sporadic observations from May 1903, systematic observations were started in October 1905, at the rate of four per month. In 1912 observations every 4 days were initiated and this level of sampling has been maintained except for a break from 17 October I939 to I6 March 1947. They provide a base to which all other observations in the area may be referred and are maintained by the Fisheries Laboratory, Lowestoft.

The observations up to 1927 have been very thoroughly reviewed by Lumby (1935) who treated the Seven Stones as 'Region no. 5'. The continuation of these Tables is presented here as Table I. The monthly mean for three periods are presented in Table 2.

TABLE 2. LONG-TERM MEANS FOR TEMPERATURE AND SALINITY AT THE SURFACE AT SEVEN STONES LIGHT VESSEL $\left(50^{\circ} 03^{\prime} \mathrm{N}\right.$., $6^{\circ} 05^{\prime} \mathrm{W}$.)

\begin{tabular}{|c|c|c|c|c|c|c|}
\hline \multirow[b]{2}{*}{ Month } & \multicolumn{3}{|c|}{$\begin{array}{l}\text { Temperature } \\
\left({ }^{\circ} \mathrm{C}\right)\end{array}$} & \multicolumn{3}{|c|}{$\underbrace{\substack{\text { Salinity } \\
(\%)}}_{(\%)}$} \\
\hline & $1905-27$ & I928-39 & $1947-58$ & $1904-27$ & 1928-39 & $1947-58$ \\
\hline January & $9 \cdot 95$ & IO 14 & 10.46 & $35 \cdot 26 \mathrm{I}$ & $35 \cdot 275$ & $35 \cdot 24 \mathrm{I}$ \\
\hline $\begin{array}{l}\text { February } \\
\text { March }\end{array}$ & $\begin{array}{l}9 \cdot 38 \\
0.18\end{array}$ & 9.55 & 9.59 & 35.256 & $35 \cdot 29 \mathrm{I}$ & $35 \cdot 24 \mathrm{I}$ \\
\hline $\begin{array}{l}\text { March } \\
\text { April }\end{array}$ & $\begin{array}{l}9.18 \\
0.55\end{array}$ & $9 \cdot 33$ & $9 \cdot 47$ & $35 \cdot 248$ & $35 \cdot 272$ & $35 \cdot 242$ \\
\hline $\begin{array}{l}\text { April } \\
\text { May }\end{array}$ & $\begin{array}{r}9.55 \\
10.8 I\end{array}$ & $9 \cdot 85$ & 9.93 & $35 \cdot 245$ & $35 \cdot 278$ & $35 \cdot 242$ \\
\hline $\begin{array}{l}\text { May } \\
\text { June }\end{array}$ & $\begin{array}{l}10.81 \\
12.92\end{array}$ & II 1 II & II $\cdot I I$ & 35.225 & $35 \cdot 270$ & $35 \cdot 245$ \\
\hline $\begin{array}{l}\text { June } \\
\text { July }\end{array}$ & $12 \cdot 92$ & 13.62 & 13.33 & $35 \cdot 227$ & $35 \cdot 253$ & 35.219 \\
\hline July & 14.90 & $15 \cdot 37$ & $15 \cdot 28$ & 35.213 & $35 \cdot 245$ & $35 \cdot 17 \mathrm{I}$ \\
\hline August & 15.75 & $16 \cdot 22$ & $16 \cdot 19$ & $35 \cdot 179$ & $35 \cdot 207$ & $35 \cdot 105$ \\
\hline September & $14 \cdot 6 \mathrm{I}$ & I5.4I & 15.50 & $35 \cdot 191$ & 35.203 & 35.118 \\
\hline October & 13.28 & 13.66 & 13.99 & 35.238 & $35 \cdot 248$ & $35 \cdot 183$ \\
\hline November & II 87 & $12 \cdot 33$ & 12.63 & $35.26 \mathrm{I}$ & 35.264 & 35.270 \\
\hline December & 10.84 & II.05 & II. $5 \mathrm{I}$ & $35 \cdot 264$ & 35.265 & 35.255 \\
\hline Year & II $\cdot 92$ & $12 \cdot 30$ & $12 \cdot 42$ & $35 \cdot 234$ & $35 \cdot 256$ & 35.211 \\
\hline
\end{tabular}

Changes in the long-term means are set out in Table 3. The warming up in the years $1928-39$ was maintained during the years $1947-58$ and indeed proceeded even further during the 8 winter months September-April. The Seven Stones region has much changed as a biological habitat since the first quarter of the century.

Salinity did not follow the same pattern. It increased during the period I928-39 but has since shown a decrease. Such small changes in salinity, unlike those in temperature, are unlikely to have much effect on plants and animals.

Lumby's work covered the period up to 1927. In extending it for the Seven Stones Light Vessel up to I958 we have adhered as closely as possible to his procedure. The statistical limitations and controls which he described at length apply here also. 
TABLE 3. CHANGES IN LONG-TERM MEANS FOR TEMPERATURE AND SALINITY AT THE SURFACE AT SEVEN STONES LIGHT VESSEL $\left(50^{\circ} 03^{\prime} \mathrm{N}\right.$., $6^{\circ} 05^{\prime}$ W.)

\begin{tabular}{|c|c|c|c|c|c|c|}
\hline \multirow[b]{3}{*}{ Month } & \multicolumn{3}{|c|}{ Temperature $\left({ }^{\circ} \mathrm{C}\right)$} & \multicolumn{3}{|c|}{ Salinity $(\%)$} \\
\hline & $\begin{array}{c}\text { 1928-39 } \\
\text { less }\end{array}$ & $\begin{array}{c}\text { I947-58 } \\
\text { less }\end{array}$ & $\begin{array}{l}\text { r947-58 } \\
\text { less }\end{array}$ & $\begin{array}{c}\text { 1928-39 } \\
\text { less }\end{array}$ & $\begin{array}{c}\text { 1947-58 } \\
\text { less }\end{array}$ & $\begin{array}{c}\text { I947-58 } \\
\text { less }\end{array}$ \\
\hline & $1905-27$ & I928-39 & $1905-27$ & I904-27 & I928-39 & $1904-27$ \\
\hline January & +o.19 & +0.32 & +0.51 & +o.014 & -0.034 & -0.020 \\
\hline February & +0.17 & +0.04 & $+0.2 \mathrm{I}$ & +0.035 & -0.050 & -0.015 \\
\hline March & +0.15 & +0.14 & +0.29 & +0.024 & -0.030 & -0.006 \\
\hline April & +0.30 & +0.08 & +0.38 & +0.033 & -0.036 & -0.003 \\
\hline May & +0.30 & Nil & +0.30 & +0.045 & -0.025 & -0.020 \\
\hline June & +0.70 & -0.29 & $+0.4 \mathrm{I}$ & +0.026 & -0.034 & -0.008 \\
\hline July & +0.47 & -0.09 & +0.38 & +0.032 & -0.074 & -0.042 \\
\hline August & +0.47 & -0.03 & +0.44 & +0.028 & -0.102 & -0.074 \\
\hline September & +0.80 & +0.09 & +0.89 & +0.012 & -0.085 & -0.073 \\
\hline October & +0.38 & +0.33 & $+0.7 \mathrm{I}$ & +o.010 & -0.065 & -0.055 \\
\hline November & +0.46 & +0.30 & +0.76 & +0.003 & +0.006 & +0.009 \\
\hline December & +0.21 & +0.46 & +0.67 & +0.001 & -0.010 & -0.009 \\
\hline Year & +0.38 & $+0 \cdot 1 \mathrm{I}$ & +0.50 & +0.022 & -0.045 & -0.023 \\
\hline
\end{tabular}

\section{Observations in Fanuary-March 1950}

Throughout 1949 very warm water had been present at the Seven Stones, the maximum deviation from Lumby's monthly means for the years 1905-27, $+2.32^{\circ} \mathrm{C}$, occurring in October. The whole of 1950 was there to remain warm but less so than 1949 (Table I, Fig. 2). There may be an oscillation of temperature of approximately fortnightly period, the maximum tending to occur about the day before the new or full moon and the minimum about 5 days afterwards. A statistically sound result requires that data for a considerable number of years shall be examined. Until that is done any attempt to correlate in detail with some of the findings of Cooper, Lawford \& Veley (I960) would be forced.

Throughout January water $0.13 \%$ less saline than average (i.e. water from the northern sectors) was followed by a sudden rise of $0.12 \%$ between 29 January and I February (Fig. 2). This betokened the first arrival at the Seven Stones of a water earlier observed to the southward. The winter minimum temperature of $10.0^{\circ} \mathrm{C}$ persisted with variations of no more than $0 . \mathrm{I}^{\circ} \mathrm{C}$ from Io February to I5 March while salinity remained high $(35 \cdot 2 \%)$.

The line of surface observations no. ro from Lands End to Ushant was presented in an earlier paper (Cooper, 1960 b, Fig. 3). About I2 February there was a narrow current around Lands End, but not including the position of the Seven Stones Light Vessel, of low salinity, relatively cold water from Lyme Bay which had flowed westwards along the coasts of south Devon and Cornwall (Cooper, I958). 


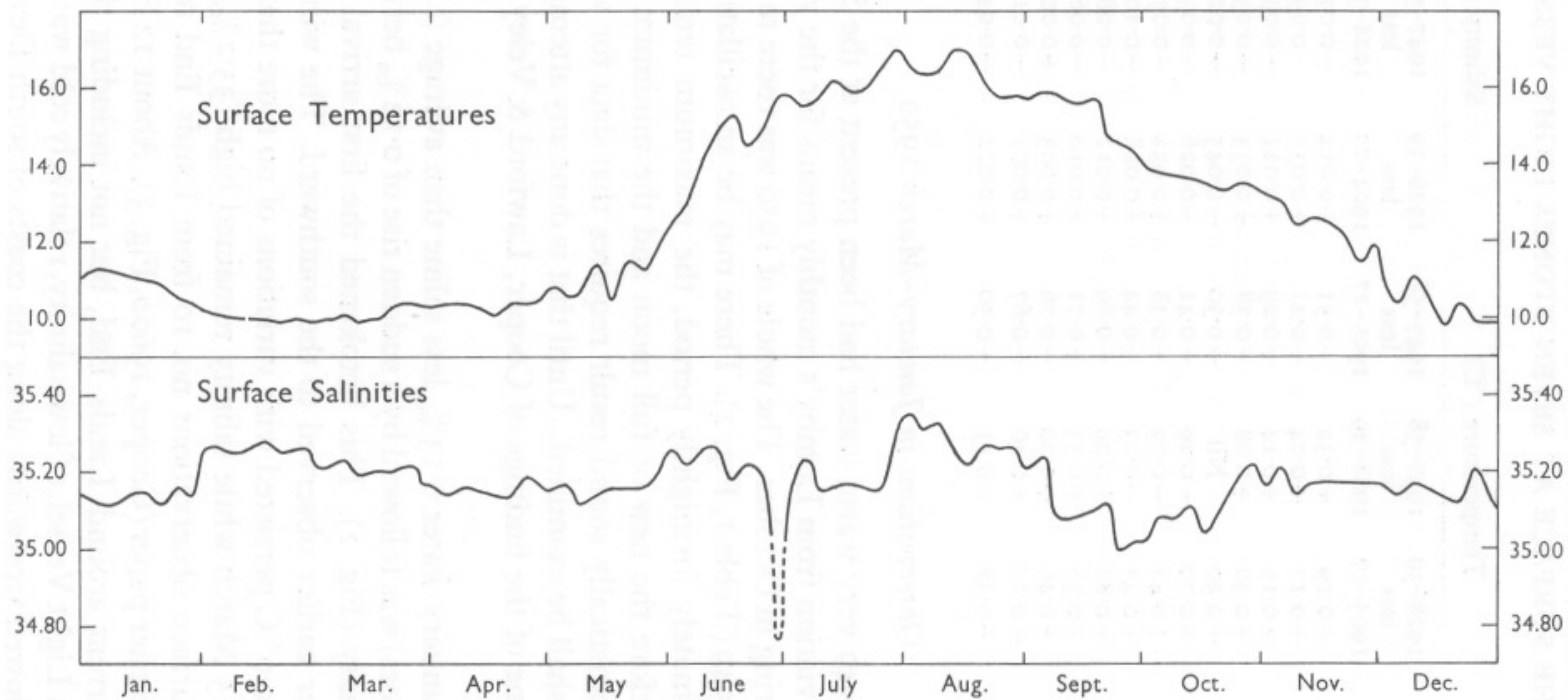

Fig. 2. Temperatures and salinities at the Seven Stones Light Vessel during 1950. 


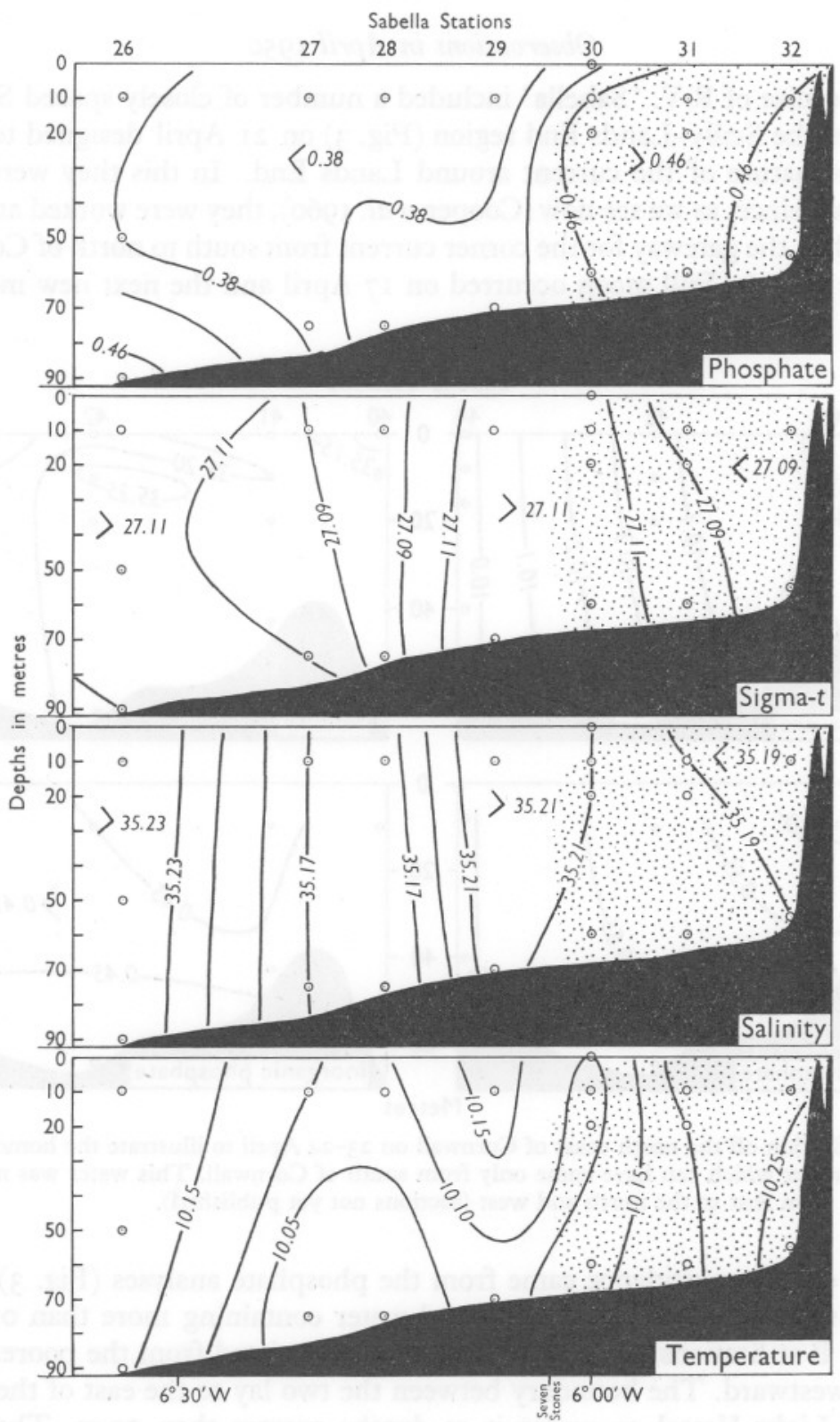

Fig. 3. Section across the Scilly-Lands End passage on 21 April for phosphate, the most informative measurement, for density and salinity, and for temperature which gave no useful information. The south Cornwall coastal water mass, revealed by phosphate, is shown stippled on each diagram. 


\section{Observations in April 1950}

The cruise of R.V. 'Sabella' included a number of closely spaced Stations 26-32 in the Scilly-Lands End region (Fig. 3) on 21 April designed to elucidate the nature of the current around Lands End. In this they were indeterminate since, as we see now (Cooper et al. 1960), they were worked at spring tides when the gateway for the corner current from south to north of Cornwall may be closed. Full moon occurred on I7 April and the next new moon on 2 May.

Sabella Stations
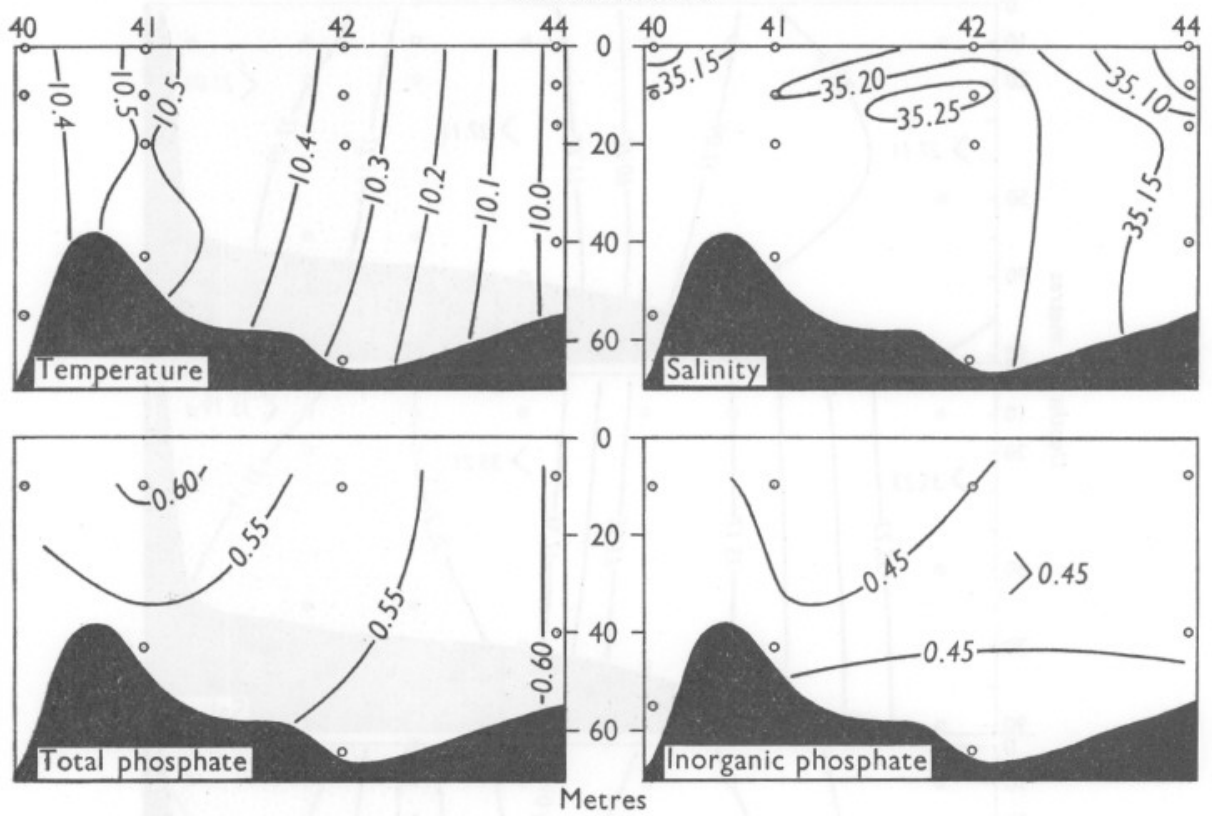

Fig. 4. Section off the north coast of Cornwall on 23-24 April to illustrate the homogeneous mass of water which can have come only from south of Cornwall. This water was markedly different from that to the north and west (sections not yet published).

The only firm evidence came from the phosphate analyses (Fig. 3) which clearly showed south Cornwall coastal water containing more than $0.46 \mu \mathrm{g}$ atom/1. P at Stations 30-32 and sharply differentiated from the poorer water to the westward. The boundary between the two lay to the east of the Seven Stones Light Vessel or under it at depths greater than $20 \mathrm{~m}$. The south Cornwall coastal water is stippled in all four panels.

Although density and salinity records showed such small gradients, nevertheless, the boundary indicated by phosphate coincides with the belt of maximum density and salinity. Such a distribution of mass would come about 
from a weak counter-current towards the north around Lands End and another weak current towards the south-east running at the surface at the light vessel and at all depths to the westwards. Temperature distribution is not in conflict with such a current system but does not indicate it.

A line of stations off the north coast of Cornwall was run on 23 April (Fig. 4). Water with the properties of Stations 40, 4I and 42 was found nowhere else north of the fiftieth parallel, but its properties were closely similar to those of the waters south of Cornwall in the weeks before (Table 4). Whatever other evidence may suggest, there can be no doubt that there had been a flow of water from the south to the north coast of Cornwall. No such continuity is traceable in any other direction through the close net of stations (Fig. I in part). The deductions of Matthews and of Harvey are strongly supported.

TABLE 4. COMPARISON BETWEEN THE WATERS NORTH, WEST AND SOUTH OF CORNWALL, APRIL, 1950

Region ...

Ship ...

Station

Date

Latitude ${ }^{\circ} \mathrm{N}$.

Longitude ${ }^{\circ} \mathrm{W}$.

Temperature ${ }^{\circ} \mathrm{C}$

Salinity \%

Density $\sigma_{t}$

Total phosphorus $\mu \mathrm{g}$-atom $/ 1$.

Phosphate-phosphorus $\mu \mathrm{g}$-atom/1.

Organic phosphorus $\mu$ g-atom/1.

Region ...

Ship ...

Station

Date

Latitude ${ }^{\circ} \mathrm{N}$.

Longitude ${ }^{\circ} \mathrm{W}$.

Temperature ${ }^{\circ} \mathrm{C}$

Salinity $\%$

Density $\sigma_{t}$

Total phosphorus $\mu$ g-atom/l.

Phosphate-phosphorus $\mu \mathrm{g}$-atom/1.

Organic phosphorus $\mu \mathrm{g}$-atom $/ 1$.

\begin{tabular}{|c|c|c|c|c|}
\hline \multicolumn{5}{|c|}{ South Cornwall } \\
\hline 'Sula' & $\begin{array}{l}\text { Interpolated } \\
\text { in time } \mathrm{L}\end{array}$ & $\begin{array}{c}\text { 'Sir } \\
\text { Lancelot' }\end{array}$ & \multicolumn{2}{|c|}{ 'Sabella' } \\
\hline $\mathrm{E}_{\mathrm{I}}$ & $\mathrm{E}_{\mathrm{I}}$ & $6 \mathrm{I}$ & 9 & IO \\
\hline 23. iii. & 2I. iv. & 8. iv. & I8. iv. & I8. iv. \\
\hline $50^{\circ} 02^{\prime}$ & $50^{\circ} 02^{\prime}$ & $49^{\circ} 5 I^{\prime}$ & $49^{\circ} 30^{\prime}$ & $49^{\circ} 32$ \\
\hline $4^{\circ} 22^{\prime}$ & $4^{\circ} 22^{\prime}$ & $4^{\circ} 00^{\prime}$ & $5^{\circ} 00^{\prime}$ & $5^{\circ} 28^{\prime}$ \\
\hline 10.15 & 10.31 & 10.35 & 10.43 & 10.50 \\
\hline $35 \cdot 30-35 \cdot 35$ & $35 \cdot 20$ & $35 \cdot 29$ & $35 \cdot 39$ & $35 \cdot 35$ \\
\hline $27 \cdot 10-27 \cdot 20$ & 27.08 & $27 \cdot 20$ & $27 \cdot 20$ & $27 \cdot 16$ \\
\hline $0.53-0.55$ & 0.53 & - & 0.69 & 0.63 \\
\hline $0.43-0.49$ & - & - & 0.40 & 0.44 \\
\hline $0.05-0.11$ & - & 一 & 0.29 & 0.19 \\
\hline \multicolumn{3}{|c|}{$\begin{array}{l}\text { Off Lands End } \\
\text { 'Sabella' }\end{array}$} & \multicolumn{2}{|c|}{$\begin{array}{l}\text { North Cornwall } \\
\text { 'Sabella' }\end{array}$} \\
\hline $3 \mathrm{I}$ & 40 & 90 & $4 \mathrm{I}$ & 42 \\
\hline $\begin{array}{l}\text { 2I. iv. } \\
50^{\circ} 04^{\prime}\end{array}$ & $\begin{array}{l}\text { 23. iv. } \\
50^{\circ} 08^{\prime}\end{array}$ & $\begin{array}{l}\text { 30. iv. } \\
50^{\circ} \mathrm{O} 2^{\prime}\end{array}$ & $\begin{array}{l}\text { 23. iv. } \\
50^{\circ} 20^{\prime}\end{array}$ & $\begin{array}{l}\text { 23. iv. } \\
50^{\circ} 42^{\prime}\end{array}$ \\
\hline $5^{\circ} 53^{\prime}$ & $5^{\circ} 53^{\prime}$ & $5^{\circ} 5 \mathrm{I}^{\prime}$ & $5^{\circ} 37^{\prime}$ & $\begin{array}{ll}50 & 42 \\
5^{\circ} & 20^{\prime}\end{array}$ \\
\hline 10.20 & 10.33 & $10 \cdot 44$ & 10.52 & 10.35 \\
\hline $35 \cdot 20$ & $35 \cdot 24$ & $35 \cdot 26$ & $35 \cdot 22$ & $35 \cdot 22$ \\
\hline $27 \cdot 10$ & $27 \cdot 10$ & 27.09 & 27.05 & $27 \cdot 10$ \\
\hline- & 0.57 & 0.56 & 0.57 & 0.54 \\
\hline 0.49 & 0.47 & $0.4 \mathrm{I}$ & 0.44 & 0.43 \\
\hline- & $0 \cdot 10$ & 0.15 & 0.13 & $0 \cdot 1 \mathrm{I}$ \\
\hline
\end{tabular}

The Seven Stones current measurements held within themselves the probable answer (Cooper et al. 1960). The eastern half of the Lands EndScilly passage may open and close to the passage of water from the south coast of Cornwall to the north like a trap door. It may open when the current at the light vessel sets to the south of its mean direction, an event favoured by neap tides and warm or very wet weather, and close when the current sets to the north of its mean position, an event favoured by spring tides and cold weather.

As we now reconstruct the occasion, water from off the south coast of 
Cornwall including the position of station $\mathrm{E}_{\mathrm{I}}$ and an interpolated position around $49^{\circ} 45^{\prime} \mathrm{N}$. lat., $4^{\circ} 40^{\prime} \mathrm{W}$. long. was being carried north-west as a counter-current towards the Runnelstone and Lands End. In this region mixing both horizontal and vertical was probably greatest at the time of springs while net northerly transport took place at neaps.

For an understanding of the oceanography of the Bristol Channel the sea area within Io miles of the Lands End promontory is of much importance and deserves much more study than we have been able to give it.
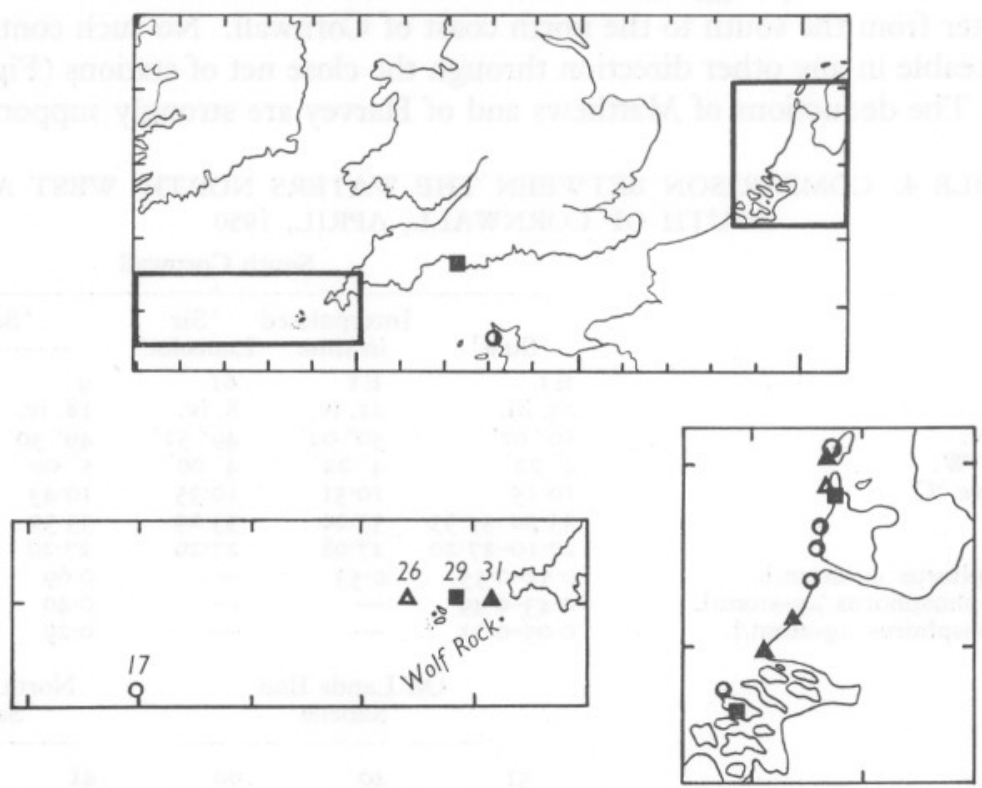

Fig. 5. Direction of surface drift. Four sets of bottles put out on 20-2I April at the positions shown by station numbers in the left inset. All recoveries are shown, most being along the Dutch coast as in the right inset.

\section{Drift-bottle results}

Four sets of surface drift bottles, provided by Mr David Vaux of the Lowestoft Laboratory, were put out from R.V. 'Sabella' during the April cruise west of Lands End. The bottles were fitted with I $m$ drags of galvanized steel; the metal caps were sealed with pitch and painted white or red. The recoveries reported by $\mathrm{Mr}$ Vaux by letter on 29 April 1952 are of much interest (Fig. 5). To facilitate comparison with Carruthers's (1927) work, his position code is included.

At Station $17\left(49^{\circ} 28^{\prime}\right.$ N., $9^{\circ}$ or W.) on 20 April 1950 at 00.25 h G.M.T. fifteen bottles were put out, of which six were recovered. Of these one travelled to Cap de la Hague $\left(\mathrm{C}_{55} \mathrm{~g}\right), 282$ miles at a rate of $\mathrm{I} \cdot 9$ miles/day. The other 
five grounded on the coast of Holland ( $\mathrm{J}_{2} \mathrm{f}, \mathrm{J} 3 \mathrm{~b}, \mathrm{~J} 5 \mathrm{i}, \mathrm{J} 4 \mathrm{~h}, \mathrm{~J} 4 \mathrm{~h} ; 5 \mathrm{II}-585$ miles) at rates between 2.4 and $3 . \mathrm{I}$ miles per day. Nine bottles were not recovered.

At Station 26 ( $50^{\circ} 04^{\prime}$ N., $6^{\circ} 34^{\prime}$ W., Io miles N.W. of the Scillies), of five bottles put out on 20 April at $23.50 \mathrm{~h}$ G.M.T. only one was recovered near den Helder, Holland (J4 c), after a journey of 476 miles at $3 \cdot 1$ miles/day. Four bottles were not recovered.

At station $29\left(50^{\circ} 04^{\prime}\right.$ N., $06^{\circ} 07^{\prime}$ W., north of the Seven Stones Light Vessel) of five bottles put out on 2 I April at 03.20 h G.M.T., one was recovered a few miles east of Bridport, Dorset (B $5 \mathrm{Id}$ ) after a minimum journey of I34 miles at a mean speed of only I'I miles per day. It is possible that this bottle, like the slow traveller stranded near Cap de la Hague, had travelled a roundabout route. Two more stranded in Holland in the mouth of the Schelde ( $\mathrm{H}_{2} \mathrm{j} ; 395$ miles at $2.8 \mathrm{miles} /$ day). Two bottles were not recovered.

At Station 3I ( $50^{\circ} 04^{\prime}$ N., $05^{\circ} 53^{\prime}$ W., 6 miles west of Lands End and where the corner current is believed to run) five bottles were put out on 2I April at 06.I 5 h G.M.T., $\mathrm{I} \frac{1}{2} \mathrm{~h}$ before high water Devonport. The tables of tidal streams (positions $E$ and $F$ ) on Admiralty Chart no. 2565 (edition published on 5 August 1955) would suggest the tide would have been making at that time about 0.9 knots towards $40^{\circ}$, but was turning rapidly towards south to reach a maximum of 2 knots towards $195^{\circ}$. The set of the tide was thus such as to carry the bottles well south of the Wolf Rock into the fairway of the English Channel before it turned.

Three bottles were recovered on the coast of Holland between Hook of Holland and Texel ( 33 ; $\left.\mathrm{J}_{2} \mathrm{a} ; \mathrm{J} 5 \mathrm{j}\right)$ after journeys of $402-458$ miles at $2 \cdot \mathrm{I}$, 2.4 and 2.5 miles per day. Two bottles were not recovered.

To sum up, from the thirty bottles put out at four positions in the Celtic Sea, eleven stranded on the coast of Holland, and one each on the mid-Channel coasts of England and France. These had drifted up-Channel with a mean speed of 2.6 miles per day. A surface skin of water had taken about 4 months to pass from end to end of the Channel. No bottles were anywhere recovered to suggest a northerly movement of surface water anywhere in the Celtic Sea. They are completely concordant with Carruthers's (1927) findings and with the pattern of currents which Carruthers et al. (I95I) drew from their measurements at the Seven Stones Light Vessel.

The remarkably high values for compounds of phosphorus in bottom water at Station 25 on April 20 (Table 5, Fig. I), and also at Station 26 can have arisen only by regeneration from the muddy deposits around the Labadie Bank or south of Ireland, as at Station 8I. Thus west of the Scillies the bottom water was moving in a direction not very different from that shown by the surface drift bottles.

The drift-bottle measurements are also in accord with Russell's (I935) deductions from biological indicators that recruitment into the English Channel 
TABLE 5. PROPERTIES OF BOTTOM WATER MOVING SOUTH-SOUTH-EAST TOWARDS THE SCILLY ISLES, 20-29 APRIL 1950

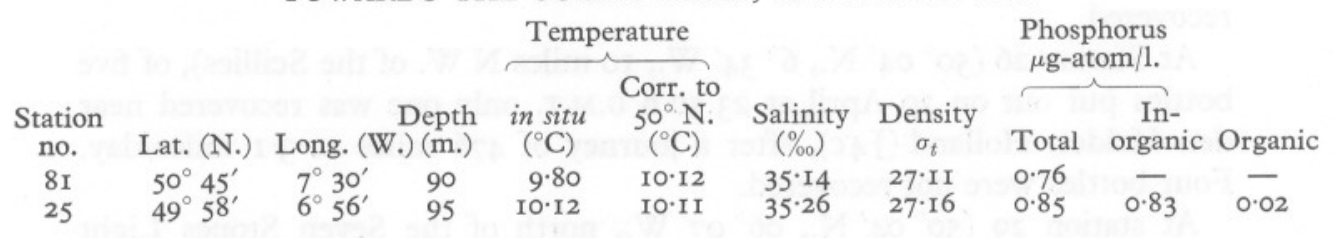

in April is of 'western' or ' elegans' type water. Moreover, the direction of flow was closely parallel with that deduced (Cooper, I $960 b$ ) from the Discovery II stations roo miles to the southward a fortnight later, i.e. in the approach to the English Channel between $48^{\circ} 20^{\prime} \mathrm{N}$. and $50^{\circ} \mathrm{N}$. lat., the flow of water was everywhere easterly or somewhat south of east.

The drift-bottle results, particularly those from Station 3I, combined with so much supporting evidence, are most unfavourable for one of the theses of this paper: that a corner current sets around Lands End from south to north.

The warm high salinity water found off north Cornwall on 23 April 1950 cannot be gainsaid. Any mechanism to get it there has to conflict with much other evidence. It seems inescapable that the current must flow with greatest strength either near the bottom or very close to Lands End, i.e. that it is intermittent and narrow and that the waters around the Longships Lighthouse need close attention.

\section{Observations in June 1950}

The 'Sabella' cruise in June I950 was designed to find the origin and the fate of the nutrient rich water found west of the Scillies in April, to explore the waters lying inshore from the continental edge, to examine further the corner currents around Ushant and Lands End and the waters north and west of Cornwall and of Brittany and to obtain 'elegans' type water for Wilson's (I95I) studies on differences between natural waters. The cruise was planned anti-clockwise but worked clockwise. Since the planned stations were not renumbered, we started with Station 34 (identical with E I) and finished with Station I (Fig. I).

\section{Stability and nutrient availability}

Information as to potential productivity of different sea areas during the summer months emerges from a comparison of adjacent stations worked on the April and June cruises (Fig. 6, Table 6).

At position $P$ well away from the nearest land and with a $I \cdot 0$ knot spring tide, the temperature below $40 \mathrm{~m}$. depth scarcely increased at all and a very strong thermocline developed (Fig. 7). The stability at positions $Q$ and $R$, similarly placed, was nearly as great. Once the spring diatom outburst was 
TABLE 6. POSITIONS WORKED IN APRIL AND JUNE 1950, STUDIED FOR STABILITY AND POTENTIAL PRODUCTIVITY

\begin{tabular}{|c|c|c|c|c|c|c|c|c|}
\hline \multirow{2}{*}{$\begin{array}{c}\text { Mean } \\
\text { position }\end{array}$} & \multirow{2}{*}{$\begin{array}{l}\text { Mean } \\
\text { lat. } \\
\text { (N.) }\end{array}$} & \multirow{2}{*}{$\begin{array}{l}\text { Mean } \\
\text { long. } \\
\text { (W.) }\end{array}$} & \multirow{2}{*}{$\begin{array}{c}\text { Distance } \\
\text { of } \\
\text { stations } \\
\text { apart } \\
\text { (miles) }\end{array}$} & \multicolumn{2}{|c|}{ April cruise } & \multicolumn{2}{|c|}{ June cruise } & \multirow{2}{*}{$\begin{array}{l}\text { Rate of } \\
\text { tidal } \\
\text { streams } \\
\text { at springs, } \\
\text { knots }\end{array}$} \\
\hline & & & & Date & Station no. & Date & Station no. & \\
\hline$P$ & $50^{\circ} 04^{\prime}$ & $7^{\circ} 29^{\prime}$ & 8 & 20 & 24 & I4 & I5 & I.O \\
\hline$Q$ & $49^{\circ} 32^{\prime}$ & $7^{\circ} 30^{\prime}$ & 4 & 19 & 14 & I4 & 17 & 0.7 \\
\hline$R$ & $50^{\circ} 39^{\prime}$ & $5^{\circ} 28^{\prime}$ & 4 & 30 & 88 & 15 & II & $I \cdot 2$ \\
\hline$S$ & $49^{\circ} 29^{\prime}$ & $4^{\circ} 5 \mathrm{I}^{\prime}$ & 12 & 18 & & 13 & 32 & I.5 \\
\hline$T$ & $50^{\circ} 04^{\prime}$ & $5^{\circ} 47^{\prime}$ & 0 & $2 \mathrm{I}-3 \mathrm{O}$ & $\begin{array}{l}31,32, \\
40,90\end{array}$ & 16 & 4 & Strong \\
\hline$U$ & $50^{\circ} 2 I^{\prime}$ & $5^{\circ} 37^{\prime}$ & 2 & 23 & $4 \mathrm{I}$ & 15 & 5 & $\mathrm{I} \cdot 4$ \\
\hline$V$ & $50^{\circ} 4 \mathrm{I}^{\prime}$ & $5^{\circ} 20^{\prime}$ & 3 & 23 & 42 & I5 & 6 & $I \cdot 4$ \\
\hline
\end{tabular}

TABLE 7. CONSUMPTION OF PHOSPHORUS COMPOUNDS

AT POSITIONS $R-V$ ( $\mu$ g-atom/1.)

For development of thermocline structure compare Fig. 7.

\begin{tabular}{|c|c|c|c|c|c|}
\hline \multirow[b]{2}{*}{ Sea area } & \multirow[b]{2}{*}{$\begin{array}{c}\text { Depth } \\
(\mathrm{m})\end{array}$} & \multicolumn{2}{|c|}{ Total phosphorus } & \multicolumn{2}{|c|}{ Inorganic phosphate } \\
\hline & & $\begin{array}{l}\text { Consumed } \\
\text { since } \\
\text { April }\end{array}$ & $\begin{array}{c}\text { Remaining } \\
\text { on } 13-16 \\
\text { June }\end{array}$ & $\begin{array}{l}\text { Consumed } \\
\text { since } \\
\text { April }\end{array}$ & $\begin{array}{c}\text { Remaining } \\
\text { on } 13-16 \\
\text { June }\end{array}$ \\
\hline $\begin{array}{l}\text { Celtic Sea away from } \\
\text { coast, position } R\end{array}$ & $\begin{array}{l}\text { 10 } \\
20 \\
40 \\
70 \\
88\end{array}$ & $\begin{array}{l}0.28 \\
0.28 \\
0.02 \\
\text { Nil } \\
\text { Nil }\end{array}$ & $\begin{array}{l}0.32 \\
0.31 \\
0.54 \\
0.57 \\
0.59\end{array}$ & $\begin{array}{c}0.26 \\
- \\
-0.05 \\
-\end{array}$ & $\begin{array}{l}0.14 \\
\frac{-}{0}\end{array}$ \\
\hline $\begin{array}{l}\text { Entrance to English } \\
\text { Channel, position } S\end{array}$ & $\begin{array}{l}0.5 \\
10 \\
20 \\
50 \\
70 \\
90\end{array}$ & $\begin{array}{l}0.25 \\
0.21 \\
0.17 \\
0.17 \\
0.26 \\
0.19\end{array}$ & $\begin{array}{l}0.46 \\
0.50 \\
0.54 \\
0.55 \\
0.42 \\
0.46\end{array}$ & $\begin{array}{l}0.24 \\
0.25 \\
0.14 \\
0.09 \\
0.06 \\
0.03\end{array}$ & $\begin{array}{l}0.18 \\
0.19 \\
0.25 \\
0.30 \\
0.31 \\
0.32\end{array}$ \\
\hline $\begin{array}{l}\text { In Lands End corner } \\
\text { current, position } T\end{array}$ & $\begin{array}{l}10 \\
48\end{array}$ & $\begin{array}{l}0.13 \\
0.20\end{array}$ & $\begin{array}{l}0.37 \\
0.30\end{array}$ & $\begin{array}{l}0.27 \\
0.27\end{array}$ & $\begin{array}{l}0.18 \\
0.18\end{array}$ \\
\hline $\begin{array}{l}\text { North-north-east of Lands } \\
\text { End, position } U\end{array}$ & $\begin{array}{l}\text { 10 } \\
20 \\
43\end{array}$ & $\begin{array}{l}0.29 \\
0.26 \\
0.19\end{array}$ & $\begin{array}{l}0.32 \\
0.31 \\
0.34\end{array}$ & $\begin{array}{l}0.24 \\
0.27 \\
0.30\end{array}$ & $\begin{array}{l}0.18 \\
0.17 \\
0.16\end{array}$ \\
\hline Position $V$ & $\begin{array}{l}0.5 \\
10 \\
20 \\
30 \\
61\end{array}$ & $\begin{array}{l}0.16 \\
0.19 \\
0.21 \\
0.23 \\
0.25\end{array}$ & $\begin{array}{l}0.36 \\
0.33 \\
0.32 \\
0.31 \\
0.31\end{array}$ & $\begin{array}{l}- \\
0.31 \\
0.25 \\
- \\
0.21\end{array}$ & $\begin{array}{l}- \\
0.14 \\
0.19 \\
- \\
0.20\end{array}$ \\
\hline
\end{tabular}

over, there could have been little replenishment of the surface water by nutrients from below.

Only at position $R$ have we data to illustrate this (Table 7). Below $40 \mathrm{~m}$. where the water had warmed up only $0.3^{\circ} \mathrm{C}$ there had been no consumption of phosphate. Vertical stability had been sufficient to immobilize the reserves in the deeper water. Only the reserves remaining in the uppermost $20 \mathrm{~m}$ were available for plant production which must subsequently have been restricted. The tidal streams around positions $P$ and $R$ may exceed I knot so 
that we may conclude that such tides running over a bottom $100 \mathrm{~m}$ deep and well away from land are unable to hinder the rapid formation and maintenance of a strong thermocline in late spring and summer.

Earlier (Cooper, 1960b) it has been deduced for the area north of Brittany that once the thermocline has developed strongly, vertical exchange across it becomes trifling and temperature in the deeper waters becomes conservative. This conclusion evidently applies at position $P$ and to a less degree at positions $Q$ and $R$, even in late spring. Moreover, any movement there may have been there between 20 April and I5 June was essentially along a west-east axis.

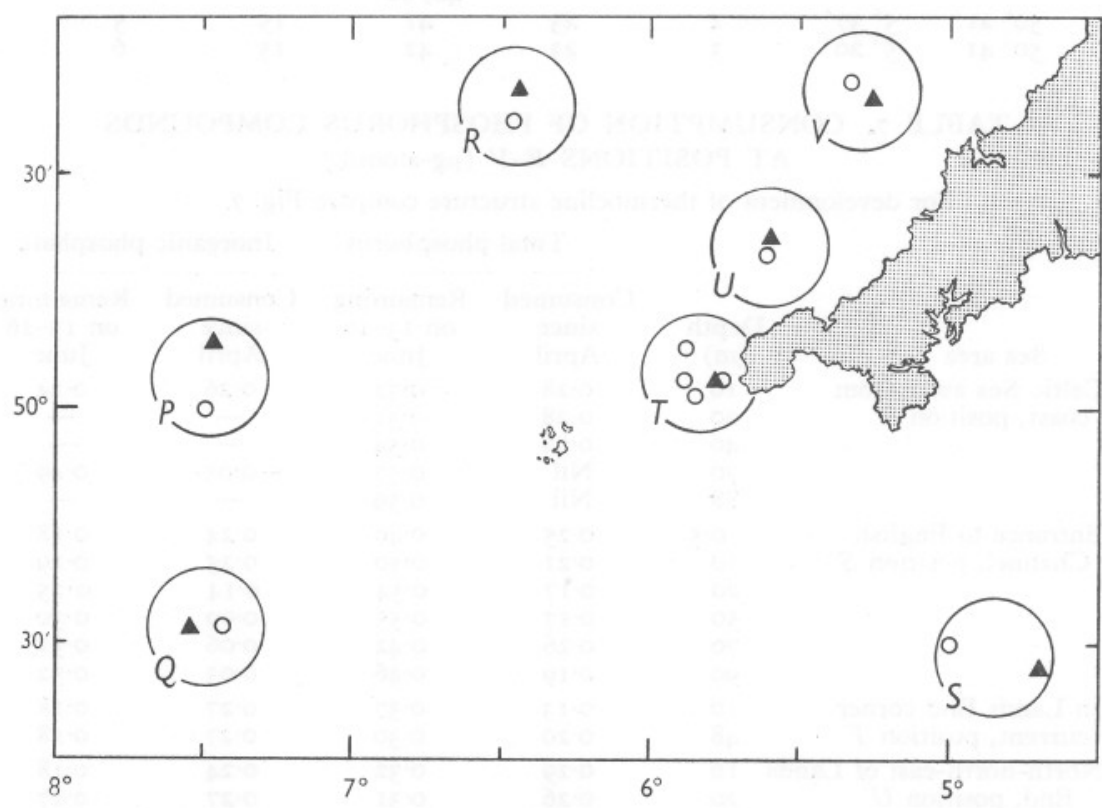

Fig. 6. Positions of stations used for the study of stability and potential productivity; open circles, April; triangles, June.

Position $S$ (Fig. 7) was on the centre line of the mouth of the English Channel and spring tides there may reach a rate of $\mathrm{I} \cdot 5$ knots. Hereabouts the deeper water warmed up by $\mathrm{I} \cdot 4^{\circ} \mathrm{C}$ and the surface layers only three-fifths as much as in the open Celtic Sea. Total phosphorus (about $0.2 \mu \mathrm{g}$-atom $/ 1$.) had been withdrawn from the whole water column into forms not sampled with the water. Inorganic phosphate had fallen by only $0.06 \mu \mathrm{g}$-atom/1., i.e. about $0.2 \mu \mathrm{g}$-atom/1. of phosphorus in organic combination had been regenerated in the deeper water.

Later in the summer it has been shown (Cooper, 1960 b) that the deeper water around position $S$ had warmed up by transport of water, with conservation of properties, from the level of the thermocline west of Ushant. 
This movement from the south-west was quite definitely not occurring in May and June 1950. It is much more probable that in spring, in an area where strong tides $(\mathrm{I} \cdot 5 \mathrm{knots}$ at springs) slow down the development of the thermocline, considerable vertical exchange by turbulence between the upper and lower layers may persist longer than where tides do not exceed I knot.

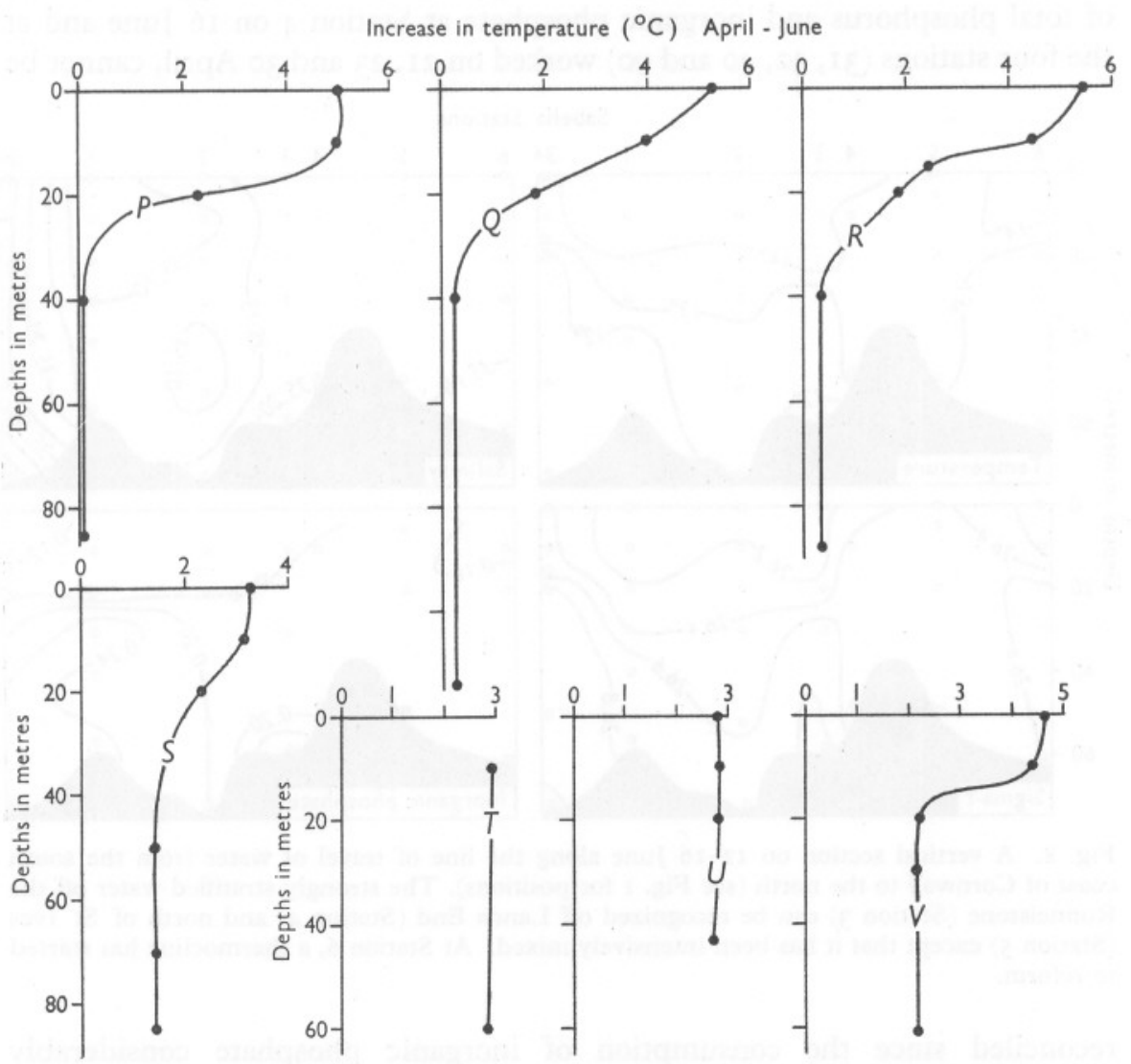

Fig. 7. Increase in temperature at seven positions (Table 6) in the Celtic Sea between 19-30 April and 13-I6 June 1950.

Consequently in the mouth of the English Channel turbulent mixing somewhere or other, but not necessarily at the place of observation, is sufficient in spring before the thermocline is fully developed to carry considerable replenishment of phosphate from the deeper reserve to the illuminated upper layers. Moreover, some of this phosphate was passing through a second cycle of utilization. Around midsummer, but not later, the position $S$ was likely to be more productive than positions $P, Q$ and $R$. 


\section{The Lands End corner current}

Position $T$ (Figs. 6, 7, 4 (Station 40) and 8 (Station 4); Tables 6 and 7) was close to Lands End in the corner current in which vertical mixing remained almost complete. The water column in June was almost isothermal (13.05$\left.13.15^{\circ}\right)$, isohaline $(35.16-35.19 \%)$ and isopycnal $(\sigma, 26 \cdot 50-26.55)$. Contents of total phosphorus and inorganic phosphate at Station 4 on I6 June and at the four stations (3I, 32, 40 and 90) worked on 2I, 23 and 30 April, cannot be

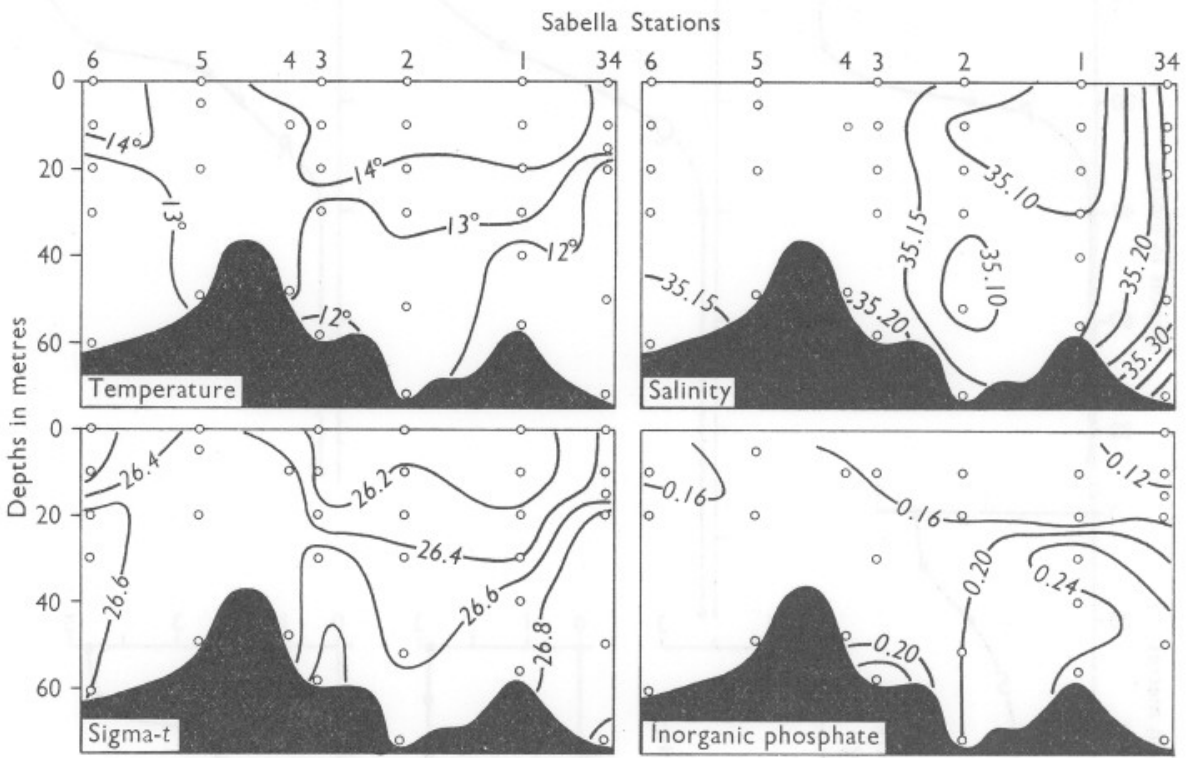

Fig. 8. A vertical section on $12-16$ June along the line of travel of water from the south coast of Cornwall to the north (see Fig. I for positions). The strongly stratified water off the Runnelstone (Station 3) can be recognized off Lands End (Station 4) and north of St Ives (Station 5) except that it has been intensively mixed. At Station 6, a thermocline has started to reform.

reconciled since the consumption of inorganic phosphate considerably exceeded the consumption of total phosphorus. Sampling in the Lands End corner current, more than in most places, is snap sampling of a highly dynamic system. The water being mixed up in June was of quite different origin from that in April. A small but distinctive water mass is created in the Lands End corner current and its components differ according to the time of year, and probably at different times in the lunar month. Consequently, in the sea area north of Cornwall an assessment of biological productivity in terms of the difference between the winter maximum and the summer minimum of inorganic phosphate is unlikely to be worth while.

The June cruise was laid out to decide whether the water lying close to 
Lands End moves north or south. Station 3 was worked one mile south of the Runnelstone. It cannot have failed to sample water escaping to the south, if any there was. The water at Station 3 was as strongly stratified as any other in the northern English Channel (Stations 34-32, 2 and I; Figs. I, 8 and 9) and more strongly than most. The water at the Runnelstone was unexceptional English Channel water, probably contributing to the corner current but very definitely receiving nothing from it.

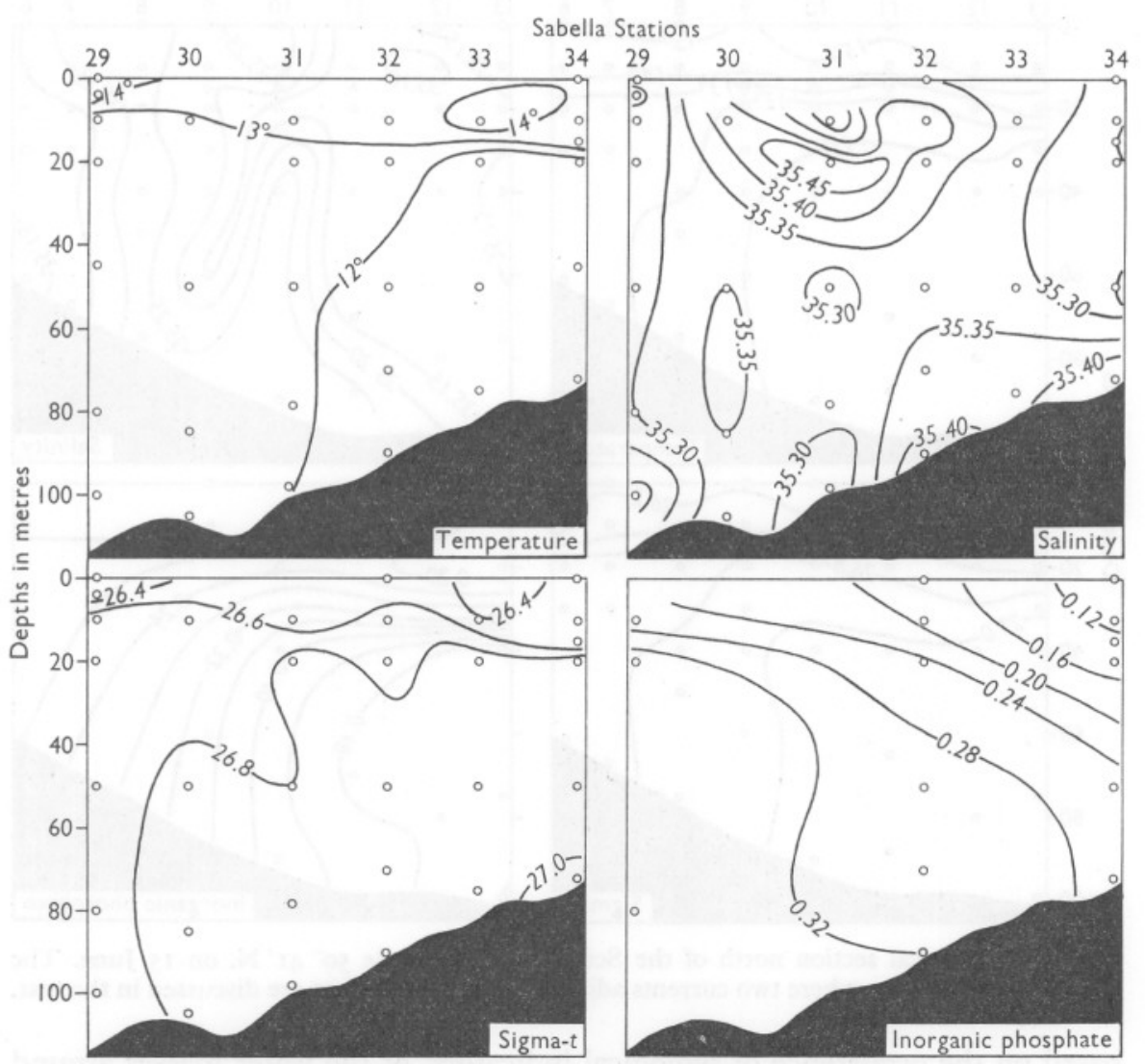

Fig. 9. A vertical section on $\mathrm{I}_{2}-\mathrm{I}_{3}$ June from near Ushant (Station 29) to E I (here Station 34).

The north Cornwall water in fune 1950

The Stations to the north (here grouped as positions $U$ and $V$; Figs. I, 6 , 7,8 and Io) present a very different story. At position $U$ (incorporating June Station 5) the whole homogeneous water column was $2 \cdot 8^{\circ}$ warmer in June than in April. The tidal stream was no stronger than at Station $S$, or off the 
Runnelstone. We had here the mixed water produced in the Lands End corner current. Its influence was still very marked at position $V$ (incorporating June Station 6) 23 miles on.

The argument for June is quite different from that used in April but is equally convincing. Much of the North Cornwall water had arrived by way of a narrow current around Lands End. Russell's illustration (1936, fig. 6),

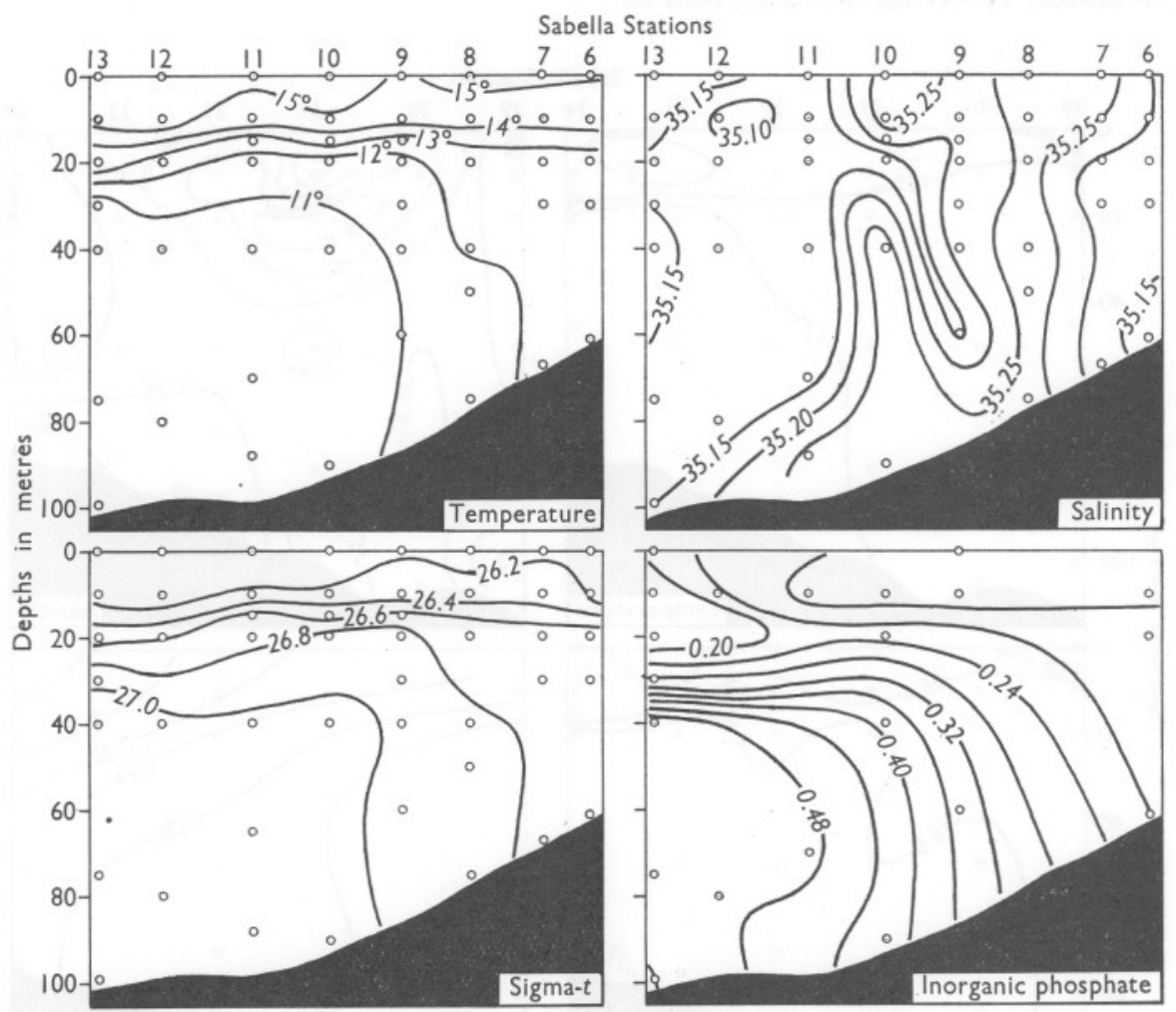

Fig. ro. A vertical section north of the Scillies along latitude $50^{\circ} 4 \mathrm{I}^{\prime} \mathrm{N}$. on $\mathrm{I} 5$ June. The doubts about the data where two currents adjoin at Stations 9 and ro are discussed in the text.

based on the occurrence of biological indicators, of the water masses around Lands End in July 1935 is in quite remarkable agreement with this account derived entirely from physical and chemical observations.

An inflexion of geopotential (Figs. Io and II) at Station Io represents clearly the western boundary of the warm and saline relatively well-mixed water emerging from the Lands End corner current (Stations 9-6) with the cold, less saline water of the Northern Celtic Sea (Stations I3-II). The June Stations 9 and ro contain anomalous salinities, confirmed by the analyst, which it is quite impossible to contour according to accepted principles of 
oceanographic presentation. The contouring in Fig. Io is the least improbable if no data are rejected. I have not attempted to reconcile $T, S$ and $\sigma_{t}$ between Stations 9 and 10 in this drawing. Either we must reject at least two duplicated analyses or we have to accept strong eddying at the current boundary with some accompanying instability, amounting to $\sigma_{t} 0 \cdot 06$. Stations $9-6$ and 5 (Figs. 8 and IO) represent a water mass in the southern entrance to the Bristol Channel with a history comparable with stations $3 \mathrm{I}$ and 30 (Fig. 9) in the southern entrance to the English Channel at the same time (Cooper, $1960 b$ ). Both had been reformed around headlands. In June I950, considered as a model, the Bristol Channel was much easier to study.

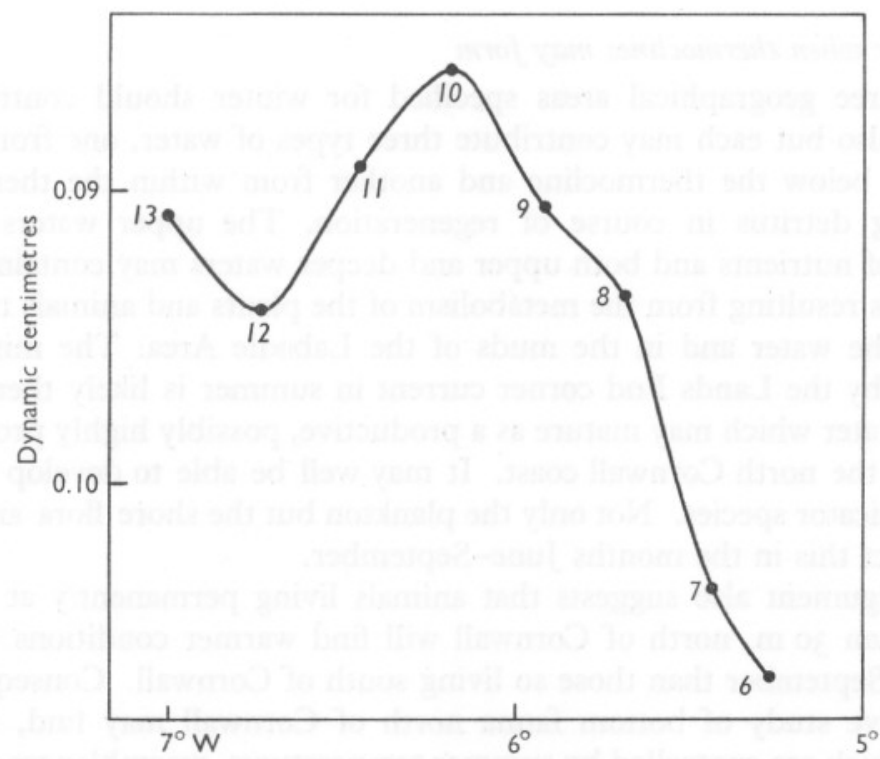

Fig. II. Geopotential heights along latitude $50^{\circ} 4 \mathrm{I}^{\prime} \mathrm{N}$. (Stations $\mathrm{I}_{3}-6$ on $\mathrm{I}_{5} \mathrm{June}$ ); surface compared with $70 \mathrm{~m}$.

The concept of narrow well-mixed corner currents running at depth round headlands and then fanning out under the influence of their momentum and the earth's rotation is a fruitful one from both a physical and biological point of view. It requires more proof than is given here, since cruises such as ours in 1950 were wrongly conceived. An understanding of corner currents requires intensive studies using a variety of techniques and spread over at least a fortnight.

Biological consequences of the Lands End corner current

Some biological consequences may also be deduced for both shore and planktonic flora and fauna of north Cornwall between Cape Cornwall and Hartland Point. 


\section{Under winter isothermal conditions}

The Lands End corner current may incorporate three types of water, (i) south Cornwall coastal water containing run-off from the rivers of south Cornwall and south Devon, (ii) water from the western approaches south of Scilly, and (iii) water from north of Scilly which the current measurements of Carruthers et al. (195I) suggest often passes the Seven Stones Light Vessel proceeding south-east. Since mixed waters are often productive there may be a tendency, but in winter no more than a tendency, for the waters north of Cornwall to be somewhat more productive than those to the west and south.

\section{In summer when thermoclines may form}

The three geographical areas specified for winter should contribute in summer also but each may contribute three types of water, one from above, one from below the thermocline and another from within the thermocline containing detritus in course of regeneration. The upper waters may be stripped of nutrients and both upper and deeper waters may contain organic substances resulting from the metabolism of the plants and animals that have lived in the water and in the muds of the Labadie Area. The mixing pot provided by the Lands End corner current in summer is likely therefore to create a water which may mature as a productive, possibly highly productive, water off the north Cornwall coast. It may well be able to develop characteristic indicator species. Not only the plankton but the shore flora and fauna may reflect this in the months June-September.

This argument also suggests that animals living permanently at a depth greater than $30 \mathrm{~m}$. north of Cornwall will find warmer conditions between July and September than those so living south of Cornwall. Consequently a comparative study of bottom fauna north of Cornwall may find, in those species which are controlled by summer temperatures, resemblances with the fauna north of Brittany rather than south of Cornwall. Setting off the twodegree difference in latitude against the secular rise in temperature in this region, comparison may prove closest between the north Cornwall bottom fauna of today with the north Brittany bottom fauna half a century or so ago.

\section{The Bristol Channel as a site for experiment}

The Bristol Channel offers a better site for experimental studies than the English Channel, because there is no eastern exit corresponding to the Straits of Dover, because it receives the largest river in England and Wales and much sewage and industrial waste, because the contrast in salinity and temperature on the north and south sides is usually greater than in the English Channel, and because the area requiring study is smaller. 


\section{A meteorological consequence of the Lands End corner current}

West Cornwall, a narrow peninsula, is well known for differences in weather between its two coasts, the north coast in popular repute being the more bracing. Between I and 5 August 1945 I was engaged in a co-operative investigation involving boats working from Falmouth (Fig. I) and aircraft based on Portreath. On the south coast the weather was superb throughout whereas the north was blanketed with fog. This fog was entered at the crest of the road between, while the aircraft had regularly to use Predannack, only I8 miles from Portreath but on the south coast, as an emergency base.

This very strong contrast evidently reflects differences in air and in sea temperatures on the two coasts. An intermittent corner current bringing variable amounts of well-mixed relatively saline water round to the north coast to replace Bristol Channel water is likely to control these local variations in weather.

The northern side of the Bristol Channel has a much more estuarine character than the northern side of the English Channel west of Start Point. The southern side of the Bristol Channel may be bathed in turn by either kind of water or by water from west of the Scillies or by mixtures of these. Waters from the south will also be subjected to vertical mixing whilst in the corner current. It is clear that an understanding of the local climate of north Cornwall, especially of fog formation, may be had only if the behaviour of the Lands End corner current is more fully understood.

I wish to acknowledge the cordial co-operation of Captain C. A. Hoodless then master of R.V. 'Sabella' and his crew, also of Mr P. G. Corbin, Mr G. A. Robinson and Mr G. R. Forster on the cruises in April and of Mr A. D. Mattacola on that in June. The salinities were determined by the Government Chemist and inorganic and total phosphorus by Mr F. A. J. Armstrong. I am also much indebted to the Lowestoft Laboratory for their assistance during the joint 1950 programme, in particular to Mr David Vaux who discussed many of the issues at the time and provided the clear-cut drift-bottle data. These have very severely restricted the possibilities that could be considered and in the end have given more confidence to the solution now presented. The paper has been illustrated by Mr G. A. Battin.

\section{SUMMARY}

Measurements of currents by meters and drift-bottles, of temperature, of salinity and of phosphate at the Seven Stones Light Vessel and in the encircling waters around Lands End and the Scilly Isles have led to conflicting conclusions on water movement. The conflict may be resolved if it is assumed that a narrow well-mixed corner current flows intermittently around Lands End 
from the south to the north coast of Cornwall. Evidence obtained in 1950 is produced in support of this deduction and supported by a development of the current measurements at the light vessel in an accompanying paper with Lawford and Veley.

It is suggested that the Lands End corner current may create conditions north of Cornwall to encourage development in summer of a small but characteristic biological community on the shore and on the off-lying sea bed and to create a local climate rather different from that off the south coast.

The Bristol Channel is considered to offer a better site for experimental oceanography than the English Channel.

Information on the effect of tidal streaming on biological productivity in summer is presented.

Temperature of the water at the Seven Stones Light Vessel has increased on average by about $0.3^{\circ} \mathrm{C}$ in the spring months and by about $0.7^{\circ} \mathrm{C}$ in autumn.

\section{REFERENCES}

CARRUTHERS, J. N., 1927. Investigations upon the water movements in the English Channel. Summer 1924. F. mar. biol. Ass. U.K., Vol. I4, pp. 685-72I.

- 1934. The flow of water past the Seven Stones Light-vessel. F. mar. biol. Ass. U.K., Vol. 19, pp. $921-30$.

Carruthers, J. N., Lawford, A. L. \& Veley, V. F. C., I95I. Studies of water movements and winds at various lightvessels. II. At the Seven Stones Lightvessel near the Scilly Isles. F. mar. biol. Ass. U.K., Vol. 29, pp. 587-608.

COOPER, L. H. N., I958. Consumption of nutrient salts in the English Channel as a means of measuring production. Rapp. Cons. Explor. Mer, Vol. I44, pp. 35-7.

- $1960 \mathrm{a}$. Some theorems and procedures in shallow water oceanography. F. mar. biol. Ass. U.K., Vol. 39, pp. I55-71.

- $1960 b$. The water flow into the English Channel from the south-west. F. mar. biol Ass. U.K., Vol. 39, pp. 173-208.

Cooper, L. H. N., Lawford, A. L. \& Veley, V. F. C., I960. On variations in the current at the Seven Stones Light Vessel. F. mar. biol. Ass. U.K., Vol. 39, pp. 659-65.

HaRvey, H. W., I925. Hydrography of the English Channel. Rapp. Cons. Explor. Mer, Vol. 37, pp. 59-89.

- 1929. Hydrodynamics of the waters south-east of Ireland. F. Cons. int. Explor. Mer, Vol. 4, pp. 80-92.

Lumby, J. R., I935. Salinity and temperature of the English Channel. Fish. Invest., Lond., Ser. 2, Vol. I4, No. 3.

Matthews, D. J., I9I4. The salinity and temperature of the Irish Channel and the waters south of Ireland. Sci. Invest. Fish. Br. Ire., I9I3, No. 4, pp. I-26.

RusSELL, F. S., I935. On the value of certain plankton animals as indicators of water movements in the English Channel and North Sea. F. mar. biol. Ass. U.K., Vol. 20, pp. 309-32.

- 1936. Observations on the distribution of plankton animal indicators made on Col. E. T. Peel's yacht 'St George' in the mouth of the English Channel, July, 1935. F. mar. biol. Ass. U.K., Vol. 20, pp. 507-22.

WIIsON, D. P., I95I. A biological difference between natural sea waters. F. mar. biol. Ass. U.K., Vol. 30, pp. I-20. 